WellBeing International

WBI Studies Repository

$1-2012$

\title{
Prevalence of Antibodies to Canine Parvovirus and Distemper Virus in Wolves in the Canadian Rocky Mountains
}

\author{
Brynn Nelson \\ University of Montana, Missoula \\ Mark Hebblewhite \\ University of Montana, Missoula \\ Vanessa Ezenwa \\ University of Montana, Missoula \\ Todd Shury \\ Western College of Veterinary Medicine \\ Evelyn H. Merrill \\ University of Alberta
}

See next page for additional authors

Follow this and additional works at: https://www.wellbeingintlstudiesrepository.org/epidem

Part of the Animal Studies Commons, Other Animal Sciences Commons, and the Veterinary Preventive Medicine, Epidemiology, and Public Health Commons

\section{Recommended Citation}

Nelson, B., Hebblewhite, M., Ezenwa, V., Shury, T., Merrill, E. H., Paquet, P. C., ... \& Webb, N. (2012).

Prevalence of antibodies to canine parvovirus and distemper virus in wolves in the Canadian Rocky

Mountains. Journal of wildlife diseases, $48(1), 68-76$.

This material is brought to you for free and open access by WellBeing International. It has been accepted for inclusion by an authorized administrator of the WBI Studies Repository. For more information, please contact wbisr-info@wellbeingintl.org.

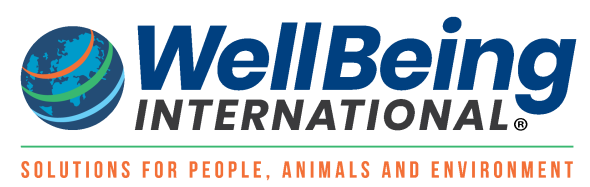




\section{Authors}

Brynn Nelson, Mark Hebblewhite, Vanessa Ezenwa, Todd Shury, Evelyn H. Merrill, Paul C. Paquet, Fiona Schmiegelow, Dale Selp, Geoff Skinner, and Nathan Webb 


\title{
PREVALENCE OF ANTIBODIES TO CANINE PARVOVIRUS AND DISTEMPER VIRUS IN WOLVES IN THE CANADIAN ROCKY MOUNTAINS
}

\author{
Brynn Nelson, ${ }^{1}$ Mark Hebblewhite, ${ }^{1,12}$ Vanessa Ezenwa, ${ }^{2,11}$ Todd Shury, ${ }^{3}$ Evelyn H. Merrill, ${ }^{4}$ \\ Paul C. Paquet, ${ }^{5,6}$ Fiona Schmiegelow, ${ }^{7}$ Dale Seip, ${ }^{8}$ Geoff Skinner, ${ }^{9}$ and Nathan Webb ${ }^{10}$ \\ ${ }^{1}$ Wildlife Biology Program, Department of Ecosystem and Conservation Sciences, University of Montana, Missoula, \\ Montana 59812, USA \\ ${ }^{2}$ Wildlife Biology Program, Division of Biological Sciences, University of Montana, Missoula, Montana 59812, USA \\ ${ }^{3}$ Department of Veterinary Pathology, Western College of Veterinary Medicine, Saskatoon, Saskatchewan S7N 5B4, \\ Canada \\ ${ }^{4}$ Department of Biological Sciences, University of Alberta, Edmonton, Alberta T6G 2E9, Canada \\ ${ }^{5}$ Raincoast Conservation Foundation, PO Box 86, Denny Island, British Columbia V0T 1B0, Canada \\ ${ }^{6}$ Faculty of Environmental Design, University of Calgary, 2500 University Drive NW, Calgary, Alberta T2N 1N4, Canada \\ 7 Department of Renewable Resources, University of Alberta, Edmonton, Alberta T6G 2E9, Canada \\ ${ }^{8}$ British Columbia Ministry of Forests, 1011 4th Ave., Prince George, British Columbia V2L3H9, Canada \\ ${ }^{9}$ PO Box 10, Parks Canada, Jasper National Park, Jasper, Alberta T1K 1M0, Canada \\ ${ }^{10}$ Department of Biological Sciences, University of Alberta, Edmonton, Alberta T6G 2E9, Canada \\ ${ }^{11}$ Current address: Odum School of Ecology, University of Georgia, Athens, Georgia 30602, USA \\ ${ }^{12}$ Corresponding author (email: mark.hebblewhite@umontana.edu)
}

ABSTRACT: Wild carnivores are often exposed to diseases via contact with peridomestic host species that travel through the wildland-urban interfaces. To determine the antibody prevalences and relationships to human activity for two common canid pathogens, we sampled 99 wolves (Canis lupus) from 2000 to 2008 for antibodies to canine parvovirus (CPV) and canine distemper virus (CDV) in Banff and Jasper National Parks and surrounding areas of the Canadian Rockies. This population was the source for wolves reintroduced into the Northern Rockies of the US. Of 99 wolves sampled, 94 had detectable antibody to CPV (95\%), 24 were antibody-positive for CDV (24\%), and 24 had antibodies to both pathogens (24\%). We tested whether antibody prevalences for CPV and CDV were higher closer to human activity (roads, town sites, First Nation reserves) and as a function of sex and age class. Wolves $\geq 2 \mathrm{yr}$ old were more likely to be have antibodies to CPV. For CDV, male wolves, wolves $\geq 2 \mathrm{yr}$, and those closer to First Nation reserves were more likely to have antibodies. Overall, however, we found minimal support for human influence on antibody prevalence for CDV and CPV. The similarity between our antibody prevalence results and results from recent studies in Yellowstone National Park suggests that at least in the case of CDV, and perhaps CPV, these could be important pathogens with potential effects on wolf populations.

Key words: Banff National Park, canine distemper virus, canine parvovirus, Canis lupus, carnivore, Jasper National Park, wolf.

\section{INTRODUCTION}

Disease has been recently recognized as a growing worldwide conservation threat for many carnivores (Murray et al., 1999). For example, wolves (Canis lupus) and many other carnivores have the potential to be exposed to canine parvovirus (CPV) and canine distemper virus (CDV) not only from other wolves, but also from hosts such as domestic and feral dogs (Canis familiaris) and alternate hosts such as coyotes (Canis latrans) and red foxes (Vulpes vulpes; Laurenson, 1998; Cleaveland et al., 2000; Almberg et al., 2010). Preva- lence of infection with carnivore pathogens such as CPV and CDV tends to increase among hosts in urban areas because of increased contact among individuals (Woodroffe et al., 2004), increasing spillover transmission rates from the reservoir hosts for wild canids (Steinel et al., 2001). For example, Mainka et al. (1994) found that domestic dogs were the main source of CPV and CDV infections in giant pandas (Ailuropoda melanoleuca) in China. Domestic and feral dogs have also been identified as the major reservoir hosts for CPV and CDV in Africa (Laurenson et al., 1998; Cleaveland et al., 2000). 
Both CPV and CDV are primarily spread by contact between individuals, and they can spread rapidly because carnivores such as wolves have high dispersal rates, disperse over wide distances, and have large home ranges (Murray et al., 1999; Woodroffe et al., 2004). Canine parvovirus is often spread through fecal-oral contact, it causes diarrhea, fever, and dehydration (Murray et al., 1999; Sobrino et al., 2008), and it infects a broad range of age classes; however, mortality primarily occurs in pups less than 4 mo old (Steinel et al., 2001; Carmichael, 2005). Canine distemper virus is a morbillivirus that infects all ages of canids (Sobrino et al., 2008), causing pneumonia, encephalitis, and sometimes death (Murray et al., 1999; Zarnke et al., 2004). Canine parvovirus has a lower case fatality rate than CDV (Murray et al., 1999). For more detail about CPV and CDV, see Murray et al. (1999), Sobrino et al. (2008), and Almberg et al. (2010). Both CPV and CDV infect many carnivore species, and they are often spread by domestic canids (Murray et al., 1999; Woodroffe et al., 2004). Carnivore reintroduction and restoration efforts must therefore carefully consider disease as an important risk factor in conservation plans (Murray et al., 1999).

Recent wolf reintroduction success in the western US (Bangs and Fritts, 1996; US Fish and Wildlife Service, 2009) has resulted in a population of over 1,500 wolves. Recently, in the Great Lakes and Yellowstone National Park wolf populations, Mech et al. (2008) and Almberg et al. (2009) reported evidence that CPV and CDV infection had negative effects on pup survival and hence population growth. Effective wolf management plans should acknowledge the potential population impacts of disease outbreaks on wolves (e.g., Montana Fish, Wildlife, and Parks, 2002). Many recovering wolf populations are exposed to overlapping host species and are close to human activity, potentially increasing disease exposure. However, compared to African carnivores, little is known about the effects of human activity on wolf diseases.

We examined prevalence of antibodies to CPV and CDV in the Canadian Rockies, the original source for reintroduced wolves into the northwest US (Bangs and Fritts, 1996). We predicted that prevalences of antibodies to both pathogens would increase closer to human activity (e.g., towns), because of higher population densities of host reservoirs (domestic dogs) and alternate hosts in valley bottoms. We also predicted that antibody prevalences would be higher near First Nation reserves, because feral dog populations associated with First Nation reserves are often unvaccinated (e.g., Woodroffe et al., 2004). We determined the occurrence of these pathogens in wolves at varying distances from human activity measured as distances to towns, First Nation reserves, and roads. We examined the effects of age and sex on CPV and CDV antibody prevalence (Zarnke et al., 2004), and predicted that prevalence would increase with age and home range size because of the increased likelihood of exposure in older wolves and greater exposure rates (Almberg et al., 2009).

\section{MATERIALS AND METHODS}

\section{Study area}

Our study area included Banff National Park, Jasper National Park $\left(52^{\circ} 15 \mathrm{~N}, 115^{\circ} 30 \mathrm{~W}\right)$, and adjacent areas to the east and north (Fig. 1), covering approximately $80,000 \mathrm{~km}^{2}$ (Thiessen, 2007). Three major highways, secondary roads, and towns and cities occur throughout the study area, and Jasper and Banff National Parks each receive two to three million visitors per year. The northern portion of the study area has fewer residents and roads, so there is a south to north gradient of decreasing human activity. Within the study area, there are First Nation reserves belonging to the Cree, Nakota Sioux, and other First Nations peoples (Statistics Canada, 2006). See Dekker et al. (1995) and Hebblewhite et al. (2002) for details of the study area.

Wolves in our study area went through two periods of scarcity, once in the 1900 s to 1920 s 


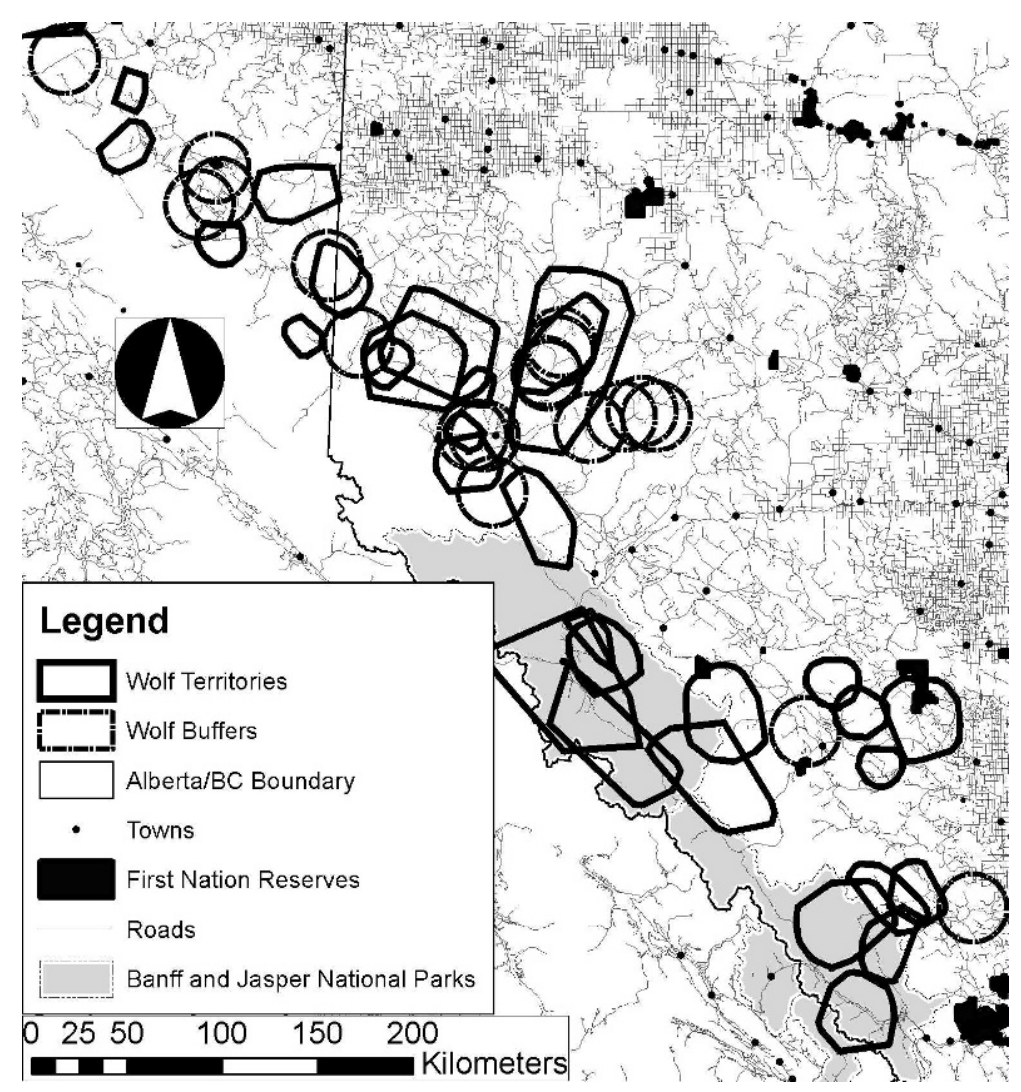

Figure 1. Study area in the Canadian Rocky Mountains of Alberta-British Columbia (BC), showing locations of wolf territories (from telemetry data) and buffered wolf (Canis lupus) capture locations (buffers) from which wolf blood samples were analyzed for antibodies to canine distemper virus (CDV) and canine parvovirus (CPV), 2000-2008. Locations of towns, Banff, Jasper, Kootenay, and Yoho National Park, major roads, and First Nation Reserves are shown. Wolf data were collected during previous studies (e.g., Hebblewhite et al., 2002; Whittington et al., 2005; Neufeld, 2006; Webb, 2009).

because of poisoning and destruction of prey and again in the 1950s because of poisoning (Gunson, 1992). Starting in the 1970s, wolves naturally recolonized our study area from northern Alberta (Gunson, 1992; Dekker et al., 1995). Wolves are protected from hunting and trapping in National Parks, although they are still subject to human-caused mortality from road and railway mortality (Hebblewhite et al., 2002). In both Alberta and British Columbia, wolf management consists of liberal harvest through hunting and trapping with the goal of maintaining stable populations (Gunson, 1992). Population genetics research by Thiessen (2007) confirmed that this entire area functions as one large population. Alternate host species for canid diseases include feral dogs, coyotes, mustelid species (Mustela spp.), and occasionally red foxes. Raccoons (Procyon lotor) do not occur.

\section{Wolf capture and blood sampling}

We captured wolves using foothold traps, helicopter net gunning, and ground or helicopter dart capture from 2000 to 2008 as part of ongoing research projects (Hebblewhite et al., 2002; Whittington et al., 2005; Neufeld, 2006; Webb, 2009). Capture methods were approved by appropriate animal care protocols (University of Alberta 353112, Parks Canada BNP004753 and JNP-2007-952, Alberta GP4816 and CN 087, WILKA101-07, British Columbia VI07-31411). For each wolf captured, we recorded age class, based on tooth wear (Gipson et al., 2000), as pups and yearlings $(<2 \mathrm{yr})$ or subadults and adults $(\geq 2 \mathrm{yr})$, sex, capture location, and wolf pack. Blood samples were collected from jugular or cephalic veins into serum separator tubes or silicone-coated tubes and allowed to clot. Clotted samples were centrifuged, and sera were pipetted into 
separate vials and stored at $-20 \mathrm{C}$ for up to $8 \mathrm{yr}$. Sera were tested for antibodies to CPV and CDV at the Western College of Veterinary Medicine at Saskatoon, Saskatchewan, Canada, using a hemagglutination inhibition assay and virus neutralization assay (Tizzard, 2000), respectively. Titers $\geq 1: 40$ were considered positive for $\mathrm{CPV}$, and titers $\geq 1: 12$ were considered positive for CDV.

\section{Human activity}

Because most $(90 \%)$ animals were radiocollared, we estimated wolf pack territories based on the $100 \%$ minimum convex polygons (MCP; Mohr, 1947) from very high-frequency (VHF) radio and global positioning system (GPS) telemetry data (e.g., Hebblewhite et al., 2002; Whittington et al., 2005; Neufeld, 2006; Webb, 2009). We used wolf pack MCPs to assign each pack an average human activity level to which each individual within the pack was assumed to be exposed. We used the MCP rather than capture locations of individual wolves to reflect the average exposure at the pack level. For individual wolves from unknown packs $(n=17)$, we drew a circular buffer of $1,000 \mathrm{~km}^{2}$ around the capture location to estimate exposure to human activity. The buffer size was estimated using the average MCP home range area across all radiocollared packs. Measures of human activity within each wolf pack territory were based on average distance of each pixel in the entire MCP to the closest paved road, First Nation reserve, and towns. Spatial data on human activity were obtained from the National Topographic Survey (available at http:// geogratis.cgdi.gc.ca). We first measured distance to the three human activity layers using the spatial analyst distance function in ARCGIS 9.2 (ESRI, Redlands, California, USA), which calculates a raster distance layer $\left(30-\mathrm{m}^{2}\right.$ resolution). We then measured the average distance to paved and unimproved roads, towns, and First Nation reserves for the entire wolf-pack MCP using zonal statistics. We screened for collinearity between spatial measures of human activity, and did not include variables if $|r|>0.3$ (Hosmer and Lemeshow, 2000).

\section{Statistical analyses}

We tested our main hypotheses for the effects of distances to human activity (towns, roads, and First Nation reserves), age, sex, and year on the prevalence of CPV and CDV antibodies using logistic regression to model the probability of a wolf being exposed to either CDV or CPV (Hosmer and Lemeshow,
2000). We added age and sex classes to a null model (representing constant exposure), and added all possible combinations of individual and combined covariates for our candidate set of models (15 models for each). We report odds ratios for covariates to test for effects on antibody prevalence, and evaluated significance at $\alpha=0.1$. To test our hypotheses about the effects of human activity on exposure to canine diseases, we predicted the coefficient of distance to be negative if viral antibody prevalence increased closer to human activity. The best CDV and CPV model was selected and compared using Akaike's information criteria (AIC) following Burnham and Anderson (1998). In the case of model selection uncertainty, we model-averaged across the top 0-4 $\triangle$ AIC (Burnham and Anderson, 1998). We also considered a random effect for each individual pack (including unknown pack) to accommodate potential between-pack heterogeneity in exposure to diseases (Gillies et al., 2006). Despite our best field efforts, however, wolves were not captured randomly or evenly across the study area, which might bias disease exposure results if age, sex, or packs varied over time. Therefore, before statistical analyses for risk factors, we conducted chi-square $\left(\chi^{2}\right)$ tests for significant differences across time for the sex, age, and packs that we captured wolves from.

\section{RESULTS}

From 2000 to 2008, we sampled 99 wolves from 42 packs (Fig. 1). Only five wolves were captured more than once, and, because these recaptures occurred on average $2.5 \mathrm{yr}$ apart, and because the five were not originally antibody-positive, we considered these samples independent. From a sampling viewpoint, there were no significant differences in the frequency of sexes $\left(\chi^{2} P=0.51\right)$, ages $\left(\chi^{2} P=0.31\right)$, or packs $\left(\chi^{2} P=0.41\right)$, confirming no significant sampling bias. Ninety-four wolves (95\%) were considered CPV antibodypositive (titer range $<1: 6-1: 972$ ) and 24 $(24 \%)$ were considered CDV antibodypositive (titer range $<1: 20-1: 20,480$ ), confirming a higher antibody prevalence to CPV than CDV (binomial test for overall prevalence of CPV vs. CDV antibody $P=0.001$; Table 1). Pups and yearlings had a lower CPV exposure than older 
TABLE 1. Mean and standard deviation (SD) of the prevalence (\%) of antibodies to canine parvovirus (CPV) and canine distemper virus (CDV) in wolves (Canis lupus) by age class and sex across all packs in the Canadian Rocky Mountains of Alberta and British Columbia, 2000-2008.

\begin{tabular}{lccccc}
\hline Age class $^{\mathrm{a}}$ and sex & $n$ & CPV $(\%)$ & SD & CDV $(\%)$ & SD \\
\hline Male $<2$ & 8 & 87.5 & $<0.005$ & 0 & $<0.005$ \\
Male $\geq 2$ & 35 & 97 & 0.38 & 17 & 0.12 \\
Female $<2$ & 9 & 78 & $<0.005$ & 0 & $<0.005$ \\
Female $\geq 2$ & 35 & 100 & 0.51 & 99 & 0.17 \\
Unknowns & 11 & 91 & 0.09 & 9 & 0.09 \\
\hline
\end{tabular}

${ }^{\text {a }}$ Pups and yearlings were $<2 \mathrm{yr}$ old, and subadults and adults were $\geq 2 \mathrm{yr}$ of age when captured.

age classes (Table 1). Female subadults and adults had a higher probability of exposure to CDV than male subadults and adults (Table 1).

\section{Effects of human activity}

Model selection showed that for CPV antibody prevalence, there were several models between $\triangle$ AIC 0.0 and 2.0 (Table 2), indicating model selection uncertainty, especially for human effects on CPV exposure. The top models included the variables age, sex, and distance to towns, roads, and First Nation reserves. The null model (constant) was $\triangle \mathrm{AIC}=7.9$ and was not reported. There was also no support for heterogeneity among packs in exposure to CPV because the similar model with random effects had substantially lower model weight $(\Delta \mathrm{AIC}=4.9)$. Therefore, we considered only the fixed effects from the logistic model. Although the top model for CPV was a function of distance to roads + age
$(\Delta \mathrm{AIC}=0.00, \mathrm{AIC}$ weight $=0.25 ;$ Table 2$)$, because there was substantial model selection uncertainty, a posteriori, we model averaged coefficients for CPV as a function of all covariates in Table 3 (CPV as a function of distance to towns, distance to roads, distance to First Nation reserves, age class, year, and sex). This "averaged" model was also the best CDV model (Table 2), making comparisons easier. The full CPV model was marginally significant $\left(\chi^{2}=9.97, P=0.083\right)$, yet still explained $29.9 \%$ (pseudo $R^{2}$ ) of the variation in CPV antibody prevalence (Table 3). Exposure to CPV was more likely in subadults and adults (Table 3). Males had slightly greater odds of exposure to CPV than females (Table 3). Antibody prevalence to CPV had weak and nonsignificant relationships to human covariates, likely in part because of the high prevalence of CPV relative to CDV antibody (Table 3 and Fig. 2).

TABle 2. Top canine parvovirus (CPV) and canine distemper (CDV) models for wolves (Canis lupus) in the Canadian Rocky Mountains of Alberta and British Columbia, 2000-2008. Covariates used were age, sex, year, and distance to human use. Model structure, sample size $(n)$, number of parameters $(K)$, log likelihood, change in Akaike's information criteria (AIC), and AIC weights are provided.

\section{Model structure}

$n \quad K$ Log likelihood $\Delta$ AIC AIC weights

Top CPV models

1. Distance to road + age

2. Approximate age

3. Distance to town + age

4. Distance to road + age + sex

5. Distance to First Nation reserve + age + sex

6. Age + sex

Top CDV models

1. Distance to towns + roads + First Nation reserves + age + sex $\begin{array}{llllll}78 & 6 & -30.34 & 0.00 & 0.63\end{array}$

2. Distance to First Nation reserves + age + sex $\quad \begin{array}{llllll}78 & 6 & -33.44 & 1.55 & 0.29\end{array}$ 
TABLE 3. Measures of model fit (likelihood ratio [LR], chi-square test, and $R^{2}$ ) and odds ratios, $P$-values, standard error $(\mathrm{SE})$ and $P$-values for the influence of wolf age class, sex, and distance functions $(\mathrm{km})$ on prevalence of antibodies to canine parvovirus (CPV) and canine distemper virus (CDV) for the full logistic regression model from Table 2. Canadian Rockies, Alberta, Canada, 2000-2008. Parameters in bold are statistically significant at $P=0.10$ from the full model.

\begin{tabular}{|c|c|c|c|c|c|c|}
\hline \multirow[b]{2}{*}{ LR $\chi^{2}$ test } & \multicolumn{3}{|c|}{$\mathrm{CPV}$} & \multicolumn{3}{|c|}{ CDV } \\
\hline & \multicolumn{3}{|c|}{$9.97, P=0.083$} & \multicolumn{3}{|c|}{$38.16, P<0.005$} \\
\hline \multirow[b]{2}{*}{$R^{2}$} & \multicolumn{3}{|c|}{0.299} & \multicolumn{3}{|c|}{0.434} \\
\hline & Odds ratio & SE & $P$-value & Odds ratio & SE & $P$-value \\
\hline Male & 1.22 & 1.464 & 0.81 & 0.225 & 0.170 & 0.045 \\
\hline Age $\geq 2$ & 8.89 & 2.36 & 0.06 & 3.91 & 6.97 & 0.51 \\
\hline Distance to town & 1.026 & 0.087 & 0.48 & 0.981 & 0.022 & 0.54 \\
\hline Distance to road & 1.930 & 1.09 & 0.247 & 0.789 & 0.096 & 0.109 \\
\hline Distance to First Nation reserve & 0.994 & 0.21 & 0.70 & 1.038 & 0.013 & 0.004 \\
\hline
\end{tabular}

For CDV, there were only two models in the top four $\triangle \mathrm{AIC}$, and the top model for CDV was a function of all covariates $(\Delta \mathrm{AIC}=0.00$, AIC weight $=0.628$; Table 2$)$. The null model was similarly poor-fitting as compared to the CPV model $(\triangle \mathrm{AIC}=8.1)$. The top model was significant $\left(\chi^{2}=33.9\right.$, $P \leq 0.005)$ and explained $43.4 \%$ of the variation in CDV (Table 3). Similar to $\mathrm{CPV}$, there was no support for a random effect of pack $(\Delta \mathrm{AIC}=5.9)$. Exposure to CDV in wolves was more likely for adults and subadults relative to pups and yearlings

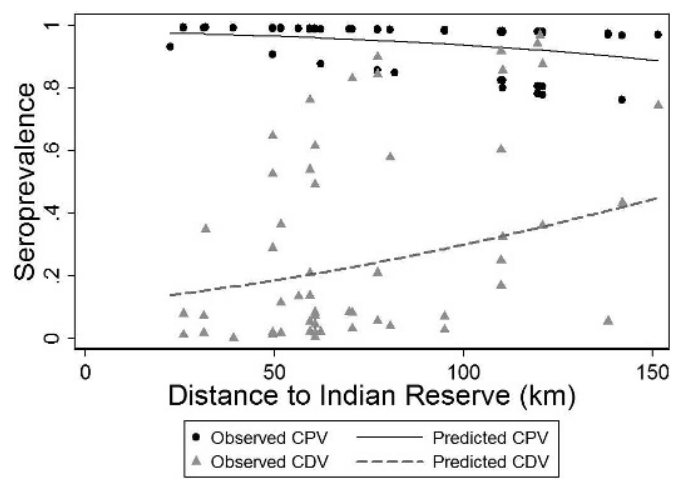

Figure 2. Observed and predicted canine parvovirus (CPV) and canine distemper (CDV) antibody prevalences as a function of distance to closest First Nation reserve for gray wolves (Canis lupus) in the Canadian Rocky Mountains of Alberta and British Columbia from 2000 to 2008. Only the relationship between CDV antibody prevalence and distance was statistically significant (see Table 3). (the intercept), and males had substantially lower odds of exposure to CDV than females (Table 3). Exposure to CDV was also significantly more likely with greater distances to First Nation reserves, although the effect size was small (Table 3 and Fig. 2). Exposure to CDV showed weak, nonsignificant declines with distance from roads but remained stable with distance from towns (Table 3).

\section{DISCUSSION}

We found that two common wolf pathogens had different antibody prevalences and age/sex differences, similar to other studied wolf populations. We found high CPV antibody prevalences in the Canadian Rockies, indicating almost all wolves sampled had been exposed to CPV. The more virulent CDV had, as expected, lower antibody prevalence (Table 1). Compared with other studies, our CPV antibody prevalence (95\%) was higher than values reported from Montana (Johnson et al., 1994: 65\%), Alaska (Zarnke et al., 2004: 35\%), Portugal (Santos et al., 2009: 32\%), and Spain (Sobrino et al., 2008: $62 \%$ ) but similar to the $100 \%$ prevalence in wolves in Yellowstone (Almberg et al., 2009, 2010). In contrast, prevalence of CDV antibody in our study $(24 \%)$ was similar to or slightly higher $(9-24 \%)$ than those reported for these 
same populations (Johnson et al., 1994; Zarnke et al., 2004; Sobrino et al., 2008; Almberg et al., 2009) and one population in Scandinavia (Akerstedt et al., 2010: $10 \%$ ). There were important and consistent effects of age and sex class on CPV and CDV antibody prevalence that were also similar to previous studies. As reported elsewhere, exposure to both CDV and CPV was higher in wolves $>2 \mathrm{yr}$ old (Zarnke et al., 2004; Sobrino et al., 2008). The fact that no pups or yearlings showed exposure to $\mathrm{CDV}$, compared to $\mathrm{CPV}$, is likely a function of the higher virulence of CDV and resultant high mortality among pups, which goes undetected in serologic tests (Almberg et al., 2009). We found weaker differences in exposure between males and females for both CPV and CDV compared to other studies (Zarnke et al., 2004).

In contrast to our hypotheses about the potential effects of human activity on wolf diseases, we found only weak evidence for human impacts on exposure to CDV or CPV, with the potential exception of First Nation reserves. Very little is known about the relationships of CPV and CDV to human activity in North America compared to studies in African carnivores (Laurenson et al., 1998; Cleaveland et al., 2000). Our results suggest that this may be due to differences in disease ecology between the two continents. In our study, the prevalence of CPV antibody was essentially high enough such that all wolves were exposed, and detection of any spatial pattern was therefore difficult. Zarnke et al. (2004) found higher antibody prevalences to CPV and other canine pathogens in remote areas compared to locations near human settlements in Alaska. We also found that CDV antibody prevalence increased primarily further from First Nation reserves, not closer, as predicted, similar to results of Zarnke et al. (2004) for CPV. The opposite effect of First Nation reserves was puzzling, but it could be explained by higher harvest of wolves by First Nation trappers near reserves, leading to lower wolf population density, and thus lower CDV transmission. Our results are also consistent with persistence in multihost communities, for example, with coyotes, similar to recent results from Yellowstone National Park (Almberg et al., 2010). Our ability to discern effects of humans on carnivore diseases through feral dogs via indirect means is probably limited and will require more detailed multihost studies to understand transmission dynamics (Almberg et al., 2010).

In the larger population of wolves in the Canadian Rockies, we present the first information about baseline infection prevalence for these two important canine pathogens. Despite the fact that we found limited evidence for human effects on wolf diseases in the Canadian Rockies, canine diseases may still have potential population impacts, for example, through reduced pup survival during outbreaks (Mech and Goyal, 1993; Almberg et al., 2010). Our results confirm that canine disease dynamics may be similar to those known from other populations, for example, differences in CPV and CDV exposure, and sex and age differences. The similarity between our results and results from nearby recovering wolf populations in Yellowstone National Park, where a potential population impact of CDV was previously detected (Almberg et al., 2009), suggests that CPV and CDV are significant and common pathogens of wolf populations that will be important to understand for wolf population management (Mech et al., 2008). Regardless of the potential role of disease on population dynamics, the most important demographic effects of humans are through direct harvest or road mortality in the Canadian Rockies (Webb et al., 2011).

\section{ACKNOWLEDGMENTS}

We thank biologists for helping us obtain samples in the field, including B. Weckworth, P. Frame, L. Neufeld, S. Slater, N. DeCesare, S. Hazenberg, H. Spaedtke, G. Kuzyk, B. Culling, D. Culling, and Bighorn Helicopters. Funding for this study was provided by Alberta Conservation Association, Alberta Fish 
and Wildlife Division, British Columbia Ministry of Environment, British Columbia Ministry of Forests, Canadian Association of Petroleum Producers, Parks Canada, Royal Dutch Shell, and World Wildlife Fund. We thank D. Pletscher and two anonymous reviewers for helpful comments on previous versions of this manuscript.

\section{LITERATURE CITED}

Akerstedt, J., A. Lillehaug, I. L. Larsen, N. E. Eide, J. M. Arnemo, and K. Handeland. 2010. Serosurvey for canine distemper virus, canine adenovirus, Leptospira interrogans, and Toxoplasma gondii in free-ranging canids in Scandinavia and Svalbard. Journal of Wildlife Diseases 46: 474-480.

Almberg, E. S., L. D. Мech, D. W. Sмith, J. W. Sheldon, and R. L. Crabtree. 2009. A serological survey of infectious disease in Yellowstone National Park's canid community. PLoS ONE 4: e7042.

—, P. C. Cross, and D. W. Smith. 2010. Persistence of canine distemper virus in the Greater Yellowstone ecosystem's carnivore community. Ecological Applications 20: 2058-2074.

Bangs, E. E., and S. H. Fritts. 1996. Reintroducing the gray wolf to central Idaho and Yellowstone National Park. Wildlife Society Bulletin 24: 402412 .

Burnham, K. P., And D. R. Anderson. 1998. Model selection and inference: A practical informationtheoretic approach. Springer-Verlag, New York, New York, 352 pp.

Carmichael, L. E. 2005. An annotated historical account of canine parvovirus. Journal Veterinary Medicine B 52: 303-311.

Cleaveland, S., M. J. Appel, W. K. Chalmers, C. Chillingworth, M. KaAre, and C. Dye. 2000. Serological and demographic evidence for domestic dogs as a source of canine distemper virus infection for Serengeti wildlife. Veterinary Microbiology 72: 217-227.

Dekker, D., W. Bradford, and J. R. Gunson. 1995. Elk and wolves in Jasper National Park, Alberta, from historical times to 1992. In Ecology and conservation of wolves in a changing world, L. N. Carbyn, S. H. Fritts and D. R. Seip (eds.). Canadian Circumpolar Institute. Edmonton, Alberta, Canada, pp. 85-93.

Gillies, C., M. Hebblewhite, S. E. Nielsen, M. Krawchuk, C. Aldridge, J. Frair, C. Stevens, D. J. SAher, And C. Jerde. 2006. Application of random effects to the study of resource selection by animals. Journal of Animal Ecology 75: 887-898.

Gipson, P. S., W. B. Ballard, R. M. Nowak, and L. D. Mech. 2000. Accuracy and precision of estimating age of gray wolves by tooth wear. Journal of Wildlife Management 64: 752-758.
Gunson, J. R. 1992. Historical and present management of wolves in Alberta. Wildlife Society Bulletin 20: 330-339.

Hebblewhite, M., D. H. Pletscher, and P. C. PAQueT. 2002. Elk population dynamics in areas with and without predation by recolonizing wolves in Banff National Park, Alberta. Canadian Journal of Zoology 80: 789-799.

Hosmer, D. W., and S. Lemeshow. 2000. Applied Logistic Regression. John Wiley and Sons, New York, New York, 322 pp.

Johnson, M. R., D. K. Boyd, And D. H. Pletscher. 1994. Serologic investigations of canine parvovirus and canine distemper in relation to wolf (Canis lupus) pup mortalities. Journal of Wildlife Disease 30: 270-273.

Laurenson, K., C. Sillero-Zubiri, H. Thompson, F. Shiferaw, S. Thirgood, and J. Malcolm. 1998. Disease as a threat to endangered species: Ethiopian wolves, domestic dogs and canine pathogens. Animal Conservation 1: 273-280.

Mainka, S. A., Q. Xianmeng, H. Tingmei, and M. J. Appel. 1994. Serologic survey of giant pandas (Ailuropoda melanoleuca) and domestic dogs and cats in the Wolong Reserve, China. Journal of Wildlife Disease 30: 86-89.

Mech, L. D., AND S. M. Goyal. 1993. Canine parvovirus effect on wolf population change and pup survival. Journal of Wildlife Disease 29: 330_333.

, W. J. Paul, and W. E. Newton. 2008. Demographic effects of canine parvovirus on a free-ranging wolf population over 30 years. Journal of Wildlife Diseases 44: 824-836.

Monr, C. O. 1947. Table of equivalent populations of North American mammals. American Midland Naturalist 37: 223-249.

Montana Fish, Wildlife, and Parks. 2002. Montana Wolf Conservation and Management Planning Document. Montana Department of Fish, Wildlife and Parks, Helena, Montana, 96 pp.

Murray, D. L., C. A. Kapke, J. F. Evermann, and T. K. Fuller. 1999. Infectious disease and the conservation of free-ranging large carnivores. Animal Conservation 2: 241-254.

Neufeld, L. 2006. Spatial dynamics of wolves and woodland caribou in an industrial forest landscape in west-central Alberta. University of Alberta, Edmonton, Alberta, Canada, 136 pp.

Santos, N., C. Almendra, and L. Tavares. 2009. Serologic survey for canine distemper virus and canine parvovirus in free-ranging wild carnivores from Portugal. Journal of Wildlife Diseases 45: 221-226.

Sobrino, R., M. C. Arnal, D. F. Luco, and C. Gortazar. 2008. Prevalence of antibodies against canine distemper virus and canine parvovirus among foxes and wolves from Spain. Veterinary Microbiology 126: 251-256.

Statistics Canada. 2006. Census 2006. Government of Canada, Statistics Canada, Ottawa, Ontario, 
Canada, www12.statcan.ca/census-recensement/ index-eng.cfm. Accessed September 2011.

Steinel, A., C. R. Parrish, M. E. Bloom, and U. Truyen. 2001. Parvovirus infections in wild carnivores. Journal of Wildlife Diseases 37: 594-607.

Thiessen, C. D. 2007. Population structure and dispersal of wolves (Canis lupus) in the Canadian Rocky Mountains. Masters Thesis, Ecology and Environmental Biology, Department of Biological Sciences, University of Alberta, Edmonton, Alberta, Canada, 88 pp.

Tizzard, I. R. 2000. Veterinary immunology; an introduction. 6th Editon. W. B. Saunders Company, Philadelphia, Pennsylvania, 311 pp.

U.S. Fish And Wildlife Service. 2009. Rocky Mountain wolf recovery 2008 interagency annual report., C. A. Sime and E. E. Bangs (eds.). US Fish and Wildlife Service. Ecological Services, Helena, Montana, www.fws.gov/mountain-prairie/species/ mammals/wolf/annualrpt08/. Accessed September 2011.
Webb, N. F., J. R. Allen, and E. H. Merrill. 2011. Demography of a harvested population of wolves (Canis lupus) in west-central Alberta, Canada. Canadian Journal of Zoology 89: 744-752.

Whittington, J., C. C. St. Clair, and G. Mercer. 2005. Spatial responses of wolves to roads and trails in mountain valleys. Ecological Applications 15: 543-553.

Woodroffe, R., S. Cleaveland, O. Courtenay, M. K. Laurenson, and M. Artois. 2004. Infectious disease in the management and conservation of wild canids. In D. W. MacDonald and C. Sillero-Zubiri (eds.). Biology and conservation of wild canids. Oxford University Press, Oxford, UK, pp. 123-142. Zarnke, R. L., J. V. Hoef, and R. A. Delong. 2004. Serologic survey for selected disease agents in wolves (Canis lupus) from Alaska and the Yukon territory, 1984-2000. Journal of Wildlife Disease 40: 632-636.

Submitted for publication 12 September 2010. Accepted 5 September 2011. 